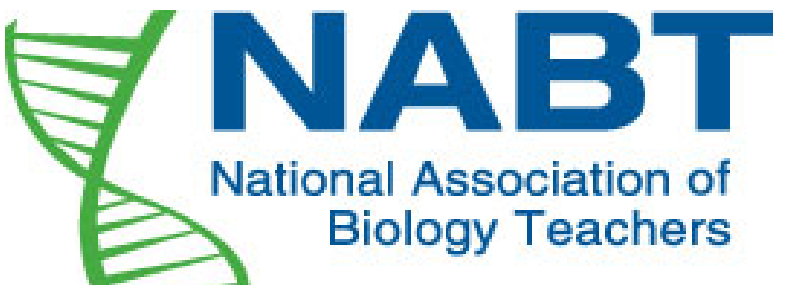

Supermarket Marine Biology

Author(s): Jennifer A. Colby, Marianne V. Moore and Gordon Estabrooks

Reviewed work(s):

Source: The American Biology Teacher, Vol. 57, No. 1 (Jan., 1995), pp. 37-39

Published by: University of California Press on behalf of the National Association of Biology Teachers

Stable URL: http://www.jstor.org/stable/4449911

Accessed: 06/06/2012 14:26

Your use of the JSTOR archive indicates your acceptance of the Terms \& Conditions of Use, available at http://www.jstor.org/page/info/about/policies/terms.jsp

JSTOR is a not-for-profit service that helps scholars, researchers, and students discover, use, and build upon a wide range of content in a trusted digital archive. We use information technology and tools to increase productivity and facilitate new forms of scholarship. For more information about JSTOR, please contact support@jstor.org. 


\title{
Supermarket Marine Biology
}

\author{
Jennifer A. Colby Marianne V. Moore Gordon Estabrooks
}

Access to living marine organisms is often difficult or costly for biology teachers or professors working in geographical locations distant from the coast. Although living or preserved organisms are available from biological supply companies, the expense is sometimes prohibitive. Also, nonliving specimens ordered from such companies are frequently preserved in toxic chemicals (i.e. formalin), making dissections and observations unpleasant and perhaps unsafe for students. Furthermore, student objections to dissections because of concerns for animal rights and biodiversity make the use of living animals in the lab or classroom particularly attractive.

We discovered that a variety of live shellfish and fresh, intact finfish (containing viscera) are available in local supermarkets in Massachusetts. Live shellfish that are available during the academic year include the American lobster (Homarus americanus), hardand soft-shelled clams (Mercenaria mercenaria and Mya arenaria), blue mussels (Mytilus edulis), periwinkles (Littorina littorea), and the American oyster (Crassostrea virginica). These species, with the exception of blue mussels, can be kept alive in the classroom for several months in a saltwater aquarium. Examples of intact finfish that are available include the Atlantic mackerel (Scomber scombrus), winter flounder (Pseudopleuronectes americanus) and Atlantic salmon (Salmo salar).

We suspected that grocery stores located a considerable distance from the coast might also offer a similar variety of live or fresh marine organisms suitable for classroom use. To test our idea, we surveyed the availability of intact marine vertebrates and live

Jennifer A. Colby and Marianne V. Moore teach in the Department of Biological Sciences at Wellesley College, Wellesley, MA 02181-8283. Gordon Estabrooks is at Boston Latin School, 78 Avenue Louis Pasteur, Boston, MA 02115. invertebrates in supermarkets in landlocked states of the continental U.S.A. Our results show that local supermarkets frequently provide an unusual variety of living or intact marine organisms suitable for demonstrations, experiments or dissections.

\section{Survey}

Questionnaires assessing the availability of live or intact marine organisms were mailed to 350 different supermarket chains in 29 states of the continental U.S.A. The two-page questionnaire included questions regarding the species and condition (live, fresh with viscera intact, or frozen) of available shellfish (i.e. mollusks, lobsters and squid) and finfish. Questions regarding the use of fresh seaweed to pack and ship live shellfish were also included.

Names and addresses of supermarket chains in the United States were obtained from the Thomas Food Industry Register (1992). Questionnaires were mailed to store headquarters in landlocked states, plus New York and Mississippi. Stores in New York were included because the state has little coastline; and Mississippi supermarkets were included to assess the availability of marine organisms in a state bordering the Gulf of Mexico. Due to budget constraints, not all supermarket chains per state were contacted. For example, convenience stores (i.e. 7-Eleven stores) were eliminated. Also, if a state contained more than 30 supermarket chains, 20-30 of these were selected randomly for the survey.

\section{Results \& Discussion}

More than $25 \%$ of the 350 questionnaires were completed and returned. Supermarkets from 21 of the 29 states participated in the survey (Figure 1). Slightly more than $55 \%$ of the stores responding to the questionnaire sell live shellfish, fresh finfish (viscera intact), or both. According to the questionnaires, supermarkets in 16 of the 21 states sell live shellfish (Figure 1). Available species of shellfish include blue mussels (Mytilus edulis), hardand soft-shelled clams (Mercenaria mercenaria and Mya arenaria), American lobsters (Homarus americanus), and American oysters (Crassostrea virgin$i c a$ ). Twelve stores located in six states sell uncleaned finfish with viscera intact. Examples of such fish include Atlantic mackerel (Scomber scombrus), winter flounder (Pseudopleuronectes americanus), hake (Urophycis sp.), snapper (Lutjanus sp.), and porgies (family Sparidae). Eleven stores in seven states will special order a wide variety of marine organisms including the species of shellfish and finfish listed above.

Live shellfish are easily maintained in a 10-15 gallon saltwater aquarium for several months. Necessary equipment is available in local pet or fish stores and includes an aquarium (10gallon tank with cover, \$22), limestone gravel (\$10 per $25 \mathrm{lbs})$, underwater filter (\$13), and an air pump (\$20). Instant Ocean ${ }^{\mathrm{TM}}$, a mixture of marine salts that is added to distilled water to prepare sea water, costs approximately $\$ 16$ for 25 gallons. Basic care of a saltwater aquarium is outlined in Solomon (1990).

Frequently, the food of marine specimens is also available from the local grocery store. For example, lobsters and crabs are omnivorous scavengers and readily consume fresh or prefrozen shrimp and soft-shelled clams. Filter feeders such as clams and oysters consume nannoplankton; and Adey and Loveland (1991) present a list of marine protozoa that can be cultured and added to the aquarium. More convenient, however, is the use of the Marine Invertebrate Diet $(\$ 5.53$ per bottle, Carolina Biological Supply Company) which is a liquid suspension of organic food particles ranging up to 100 microns in size. 


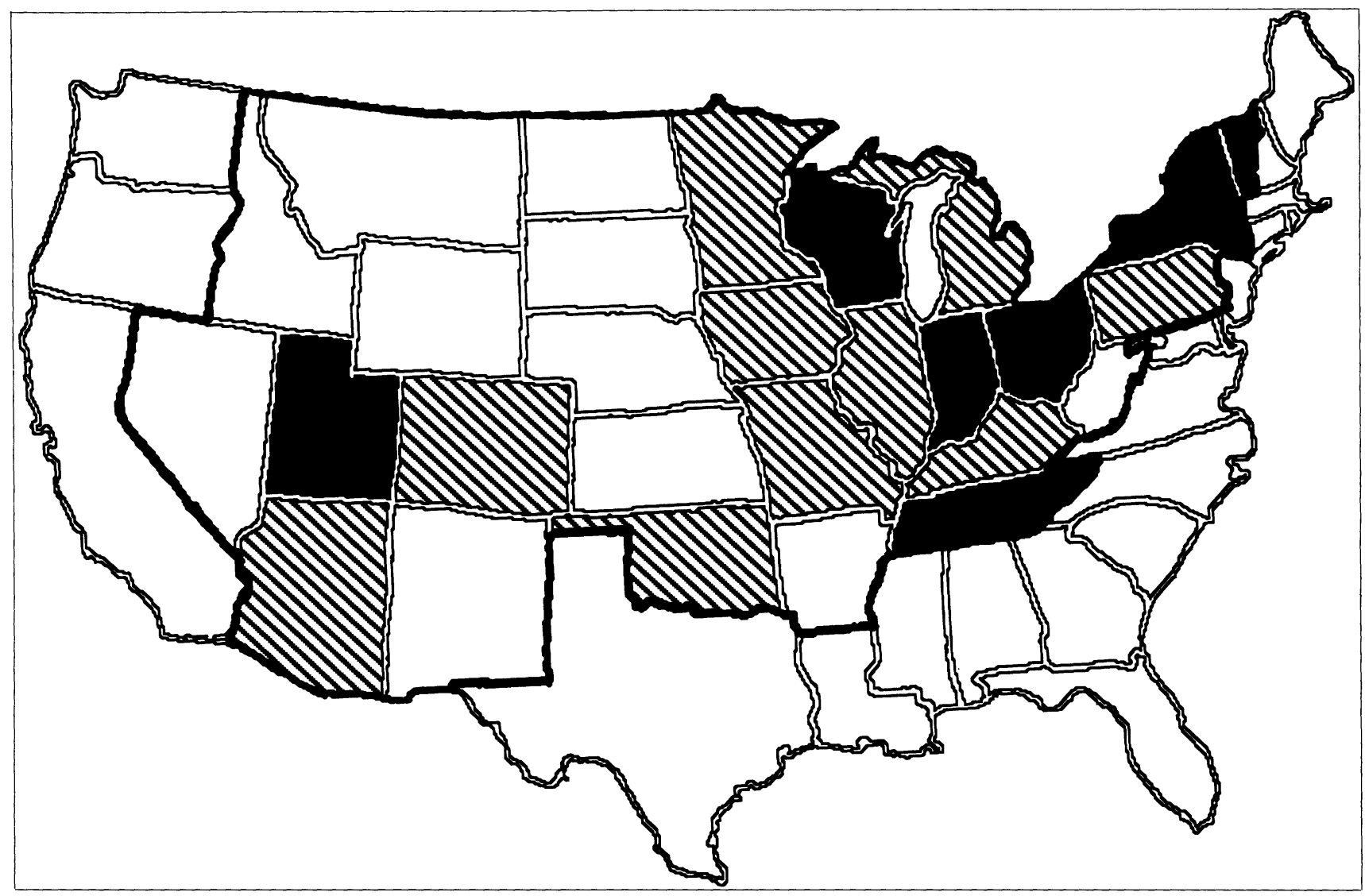

Figure 1. Questionnaires regarding the availability of marine organisms were sent to supermarket chains located in the outlined portion of the continental U.S.A. According to results of returned questionnaires, states marked with the diagonal pattern represent those containing supermarket chains that sell live shellfish. States marked with solid black indicate those containing supermarket chains that supply live shellfish as well as fresh, intact marine finfish.

The diversity of marine invertebrates in a "supermarket aquarium" can be increased greatly by placing fresh seaweed and certain species of mollusks in the aquarium. Fresh seaweed, which is often used to pack and ship live shellfish, frequently contains a fascinating array of macroinvertebrates including amphipods (beach hoppers), bryozoans, polychaetes, small gastropods, and juvenile crabs. Mollusks, particularly oysters, also

Table 1. Cost comparison of marine organisms purchased from a biological supply company and a local supermarket in Massachusetts. Retail prices in Midwestern supermarkets are either similar (i.e. mackerel) or 1.5-2× higher (soft-shelled clam and squid) than those in Massachusetts.

\begin{tabular}{|c|c|c|}
\hline \multirow[b]{2}{*}{ Species } & \multicolumn{2}{|r|}{ Supplier } \\
\hline & $\begin{array}{l}\text { A Biological Supply } \\
\text { Company }\end{array}$ & Local Supermarket \\
\hline $\begin{array}{l}\text { Soft-shelled clam } \\
\text { (Mya arenaria) }\end{array}$ & $\$ 1.72$ each & $\begin{array}{c}\$ 0.10 \text { each } \\
(\$ 1.99 / \mathrm{lb} ; 20 \text { clams }=1 \mathrm{lb})\end{array}$ \\
\hline Squid (Loligo sp.) & $\begin{array}{l}\$ 2.66 \text { each } \\
\left(<6^{\prime \prime} \text { long }\right)\end{array}$ & $\begin{array}{l}\$ 0.86 \text { each } \\
\left(\$ 2.59 / \mathrm{lb} ; 3 \text { squid } 10^{\prime \prime} \text { long }=1 \mathrm{lb}\right)\end{array}$ \\
\hline Fish & 7-9" Perch-\$1.77 each & $\begin{array}{l}\text { 11" Atlantic Mackerel }-\$ 1.50 \text { each } \\
(\$ 1.99 / \mathrm{lb} ; \text { one fish }=0.75 \mathrm{lb})\end{array}$ \\
\hline
\end{tabular}

contain interesting epifauna such as barnacles, small sea anemones and polychaetes.

Uncleaned finfish, squid and whole shellfish are ideal specimens for dissections. One of the advantages of working with fresh, uncleaned fish or squid is that the stomachs or intestines often contain remnants of identifiable prey. Gut contents can be examined and used to test student-generated hypotheses concerning the gender- or age-specificity of diet. Specimens that are preserved with harsh preservatives, however, often regurgitate their gut contents, making such observations impossible. Also, unpreserved specimens are frequently more pleasant to handle because the scent of harsh preservatives is lacking. One disadvantage of using fresh marine organisms for dissection is that some species decompose rapidly. This is particularly true of fresh squid, which should be stored on ice in the refrigerator and used on the day of purchase to avoid odor problems. 
Marine organisms purchased from a local supermarket are frequently much less expensive than those obtained from a biological supply company. This is particularly true for shellfish. For example, live soft-shelled clams (Mya arenaria) obtained from a Massachusetts supermarket are 17 times less expensive than preserved specimens marketed by a national biological supply company. Likewise, fresh squid (Loligo sp.) are three times less expensive when purchased at a supermarket. Although retail prices for shellfish in Midwestern grocery stores are 1.5 to 2 times higher than those in Massachusetts, substantial savings at a supermarket are usually possible (Table 1).

In general, finfish suitable for dissection are priced similarly by both supermarkets and biological supply companies. A greater variety of marine finfish species, however, may be available at supermarkets. For example, one biological supply company did not stock marine bony fish suitable for dissection. In contrast, supermarkets may offer as many as nine marine species.

\section{Conclusion}

The local supermarket is a rich resource for teachers of marine biology or invertebrate biology. Many stores sell a wide variety of living marine invertebrates or intact finfish that are ideal for experiments, live demonstrations or dissections. Obtaining specimens from a local grocery store is often less expensive and can be more convenient than ordering from a biological supply company.

\section{Acknowledgment}

We are grateful for the support of a Hughes Grant to Wellesley College which funded the supermarket survey.

\section{References}

Adey, W.H. \& Loveland, K. (1991). Dynamic aquaria: Building living ecosystems. San Diego: Academic Press, Inc.

Moe, A.M., Jr. (1989). The marine aquarium reference: Systems and invertebrates. FL: Green Turtle Publications.

Solomon, S. (1990). Teaching advantages in maintaining a marine aquarium. The American Biology Teacher, 52, 107-108.

Thomas Food Industry Register. (1992). Volume 1. New York: Thomas Publishing Company.

\title{
DOCTOR OF ARTS IN BIOLOGICAL SCIENCES:
}

FELLOWSHIPS are available for persons interested in the D.A. degree in Biological Sciences. The program stresses preparation for undergraduate teaching at colleges and universities. Applicants must hold a master's degree in some area of biology.

Deadline for receipt of application is 1 March 1995.

\author{
For more information contact: \\ Chairman D.A. Committee \\ Department of Biological Sciences \\ Idaho State University \\ Pocatello, ID 83209.
}

\section{An Equal Opportunity Employer.}

